NASZA DERMATOLOGIA Onlin OUR DERMATOLOGY Online

Source of Support:

Nil

Competing Interests:

None

\section{EPONYMS IN THE DERMATOLOGY LITERATURE LINKED TO STAINS USED IN SKIN BIOPSIES}

\author{
Khalid Al Aboud ${ }^{1}$, Ahmad Al Aboud ${ }^{2}$ \\ ${ }^{1}$ Department of Public Health, King Faisal Hospital, Makkah, Saudi Arabiaa \\ ${ }^{2}$ Dermatology Department, King Abdullah Medical City, Makkah, Saudi Arabia
}

Corresponding author: Dr. Khalid Al Aboud

amoa65@hotmail.com
Staining is an auxiliary technique used in microscopy to enhance contrast in the microscopic image. Stains and dyes are frequently used in biology and medicine to highlight structures in biological tissues for viewing, often with the aid of different microscopes [1].

Hematoxylin and eosin stain (H\&E stain or HE stain), is the routine staining for skin biopsies. However, in some circumstances, dermatopathologists use other stains.

For example, the Fontana-Masson Stain is used for melanin as it can be difficult to decide whether a brown pigment is lipofuscin, hemosiderin, or melanin. At $\mathrm{pH} 4$, melanin granules reduce silver nitrate to metallic silver, a histochemical reaction that reveals accumulations of black material wherever melanin is located. The Fontana-Masson Stain can be used, also, to detect melanin of dematiaceous fungi [2].

Each stain may give a particular colour to a specific structure in the tissue. For example, Alizarin red binds directly to calcium ions, resulting in an orange-red color [3].

In Foote's or Snook's stain, the reticulin fibers will be black. Leder stain (Naphthol ASD chloroacetate esterase), will stain Mast cell cytoplasm red (not dependent on presence of granules). Also stains myloid cells (example, leukemia cutis).

Lipid will be stained by Oil red $\mathrm{O}$ (requires fresh frozen tissue, as lipid is removed during processing). In addition to Sudan black and Osmium tetroxide (both require fresh tissue).

Iron will be stained by Prussian blue, also known as Perls stain, after its inventor, German pathologist Max Perls (1843-1881). In this stain ferric ions react to form a deep blue. It is useful to distinguish melanin from hemosiderin (example:hemosiderin in pigmented purpuric dermatosis). It does not demonstrate iron in intact red blood cells.

There are also several other stains which are not used commonly in dermatopathology. For example:

Movat's stain which is a pentachrome stain originally developed by Henry Zoltan Movat in 1955 and later modified by H. K. Russell, Jr. in 1972. It is used to highlight the various constituents of connective tissue. In this stain, the nuclei, elastic fibres will be black; collagen fibres, reticular fibres will be yellow; ground substance, mucin will be blue; Fibrin will be bright red Muscle will be red.

Also, Weigert's elastic stain which will show elastic fibers, blue coloured while cell nuclei gets red or blue. It is named for, Karl Weigert, or Carl Weigert (1845-1904), (Fig. 1), who was a German pathologist.

There are several eponyms linked to the stains used in dermatopathology practice. In Table I [4-19], we listed some examples.

\begin{tabular}{|c|l|}
\hline $\begin{array}{c}\text { Eponyms in the dermatology } \\
\text { literature linked to stains used in } \\
\text { skin biopsies }\end{array}$ & \multicolumn{1}{c|}{ Remarks } \\
\hline Bodian stain [4] & $\begin{array}{l}\text { Nerve fibers will appear black with this stain. Nerve fiber can also be stained by PGP 9.5 and } \\
\text { neurofilament. Named after David Bodian (1910-1992), (Fig. 2). Bodian received his Ph.D. } \\
\text { in anatomy in 1934 and his M.D. in 1937 from the University of Chicago. He made major } \\
\text { contributions to the knowledge of the basic structure of nerve cells. }\end{array}$ \\
\hline Feulgen stain [5] & $\begin{array}{l}\text { It stains, DNA magenta. Named for, Robert Feulgen (1884-1955), (Fig. 3), who was a German } \\
\text { physician and chemist. He developed a method for staining DNA, in 1914. }\end{array}$ \\
\hline
\end{tabular}

Table I. Selected Eponyms in the dermatology literature linked to stains used in skin biopsies. 


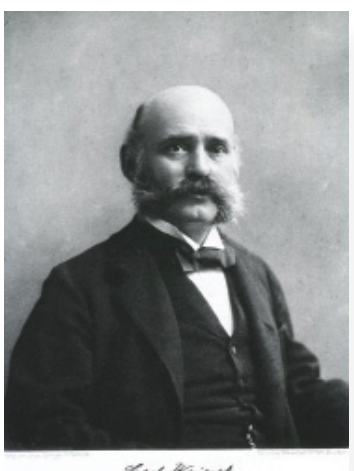

Soed trapent

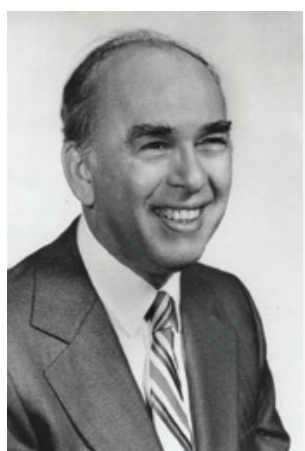

Figure 2. David Bodian (1910-1992).

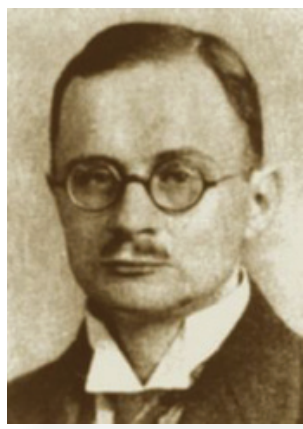

Figure 3. Robert Feulgen (1884-1955).

Figure 1. Carl Weigert (1845 -1904).

\begin{tabular}{|c|c|}
\hline $\begin{array}{l}\text { Eponyms in the dermatology } \\
\text { literature linked to stains used in } \\
\text { skin biopsies }\end{array}$ & Remarks \\
\hline Fite stain [6] & $\begin{array}{l}\text { Also known as, Fite-Faraco stain. Fite is preferred for ,partially acid-fast” organisms such as } \\
\text { lepra bacilli, atypical mycobacteria, and Nocardia.Fite preseves color due to use of peanut oil } \\
\text { before staining and gentle decolorization. } \\
\text { George Liddle Fite (1933-1993), (Fig. 4), who was arguably the most important American } \\
\text { figure in the fight against leprosy.The crowning achievement of a life devoted to the treatment of } \\
\text { leprsosy was a chief pathologist of the laboratory at the States Leprosarium in Carville, } \\
\text { Louisiana. }\end{array}$ \\
\hline Giemsa stain [7] & $\begin{array}{l}\text { It stains myeloid and mast cell granules purple (it is the heparin in the mast cells that is staining). } \\
\text { Also good for many types of organisms, including bacteria, Leishmania, and Histoplasma. } \\
\text { Gustav Giemsa (1867-1948), (Fig. 5), was a German chemist and bacteriologist who was a native } \\
\text { of Medar-Blechhammer. Giemsa improved the Romanowsky stain (Eosin Yand Methylene Blue) } \\
\text { by stabilizing this dye solution with glycerol. This allowed for reproducible staining of cells } \\
\text { for microscopy purposes. Romanowsky staining was named after the Russian Physician, Dmitri } \\
\text { Leonidovich Romanowsky (1861-1921), who invented it in } 1891 \text {. }\end{array}$ \\
\hline $\begin{array}{c}\text { Gomori's aldehyde-fuchsin stain } \\
{[8,9]}\end{array}$ & $\begin{array}{l}\text { Stain elastic tissue purple.Elastic tissue can be also stained by Verhoeff von Gieson (blue-black), } \\
\text { and by Orcein-Giemsa (black). It is named for György Gömöri also George Gömöri or George } \\
\text { Gomori or George Gömöri (1904-1957), who was a Hungarian-American physician who became } \\
\text { famous as histochemist. }\end{array}$ \\
\hline $\begin{array}{l}\text { Gomori methenamine silver (GMS) } \\
{[\text { [9] }}\end{array}$ & $\begin{array}{l}\text { Also called, Grocott-Gomori's (or Gömöri) methenamine silver stain.It is abbreviated as GMS. It } \\
\text { stains fungi which can also be stained by PAS (Periodic acid-Schiff). }\end{array}$ \\
\hline Gram staining [10] & $\begin{array}{l}\text { Gram staining (or Gram's method) is a method of differentiating bacterial species into two } \\
\text { large groups (Gram-positive and Gram-negative). Named for Hans Christian Gram (1853-1938), } \\
\text { (Fig. 6), who was a Danish bacteriologist who developed the technique while working with Carl } \\
\text { Friedländer in the morgue of the city hospital in Berlin in 1884. Brown-Hopps tissue Gram stain } \\
\text { is a modification of Brown-Brenn technique. Gram-positive organisms stain blue and Gram- } \\
\text { negative organisms stain red. }\end{array}$ \\
\hline Masson's trichrome stain [11] & $\begin{array}{l}\text { In this stain, Collagen will appear bluelgreen and muscle,nerve, and keratin will be red. It is } \\
\text { a three-colour staining protocol used in histology. The recipes evolved from Claude L. Pierre } \\
\text { Masson's, original formulation to different specific applications, but all are suited for } \\
\text { distinguishing cells from surrounding connective tissue. } \\
\text { Most recipes produce dark brown to black cell nuclei. } \\
\text { Claude L. Pierre Masson (1880-1959), (Fig. } 7 \text { ), was a French-born Canadian pathologist. } \\
\text { He was the chair of anatomic pathology at the hospital and medical school at Strasbourg, } \\
\text { France. In 1927, while he was } 46 \text { years old, Masson resigned his position at Strasbourg and a } \\
\text { ccepted the position of chief of anatomic pathology at the University of Montreal Medical School. } \\
\text { Pierre Masson died at the age of } 79 \text { years. He is buried, as he wished, at the cemetery of } \\
\text { Notre-Dame-des-Neiges, atop Mont Royal, where today one has a grand view of the University } \\
\text { of Montreal. }\end{array}$ \\
\hline
\end{tabular}

Table I. Selected Eponyms in the dermatology literature linked to stains used in skin biopsies (continued). 


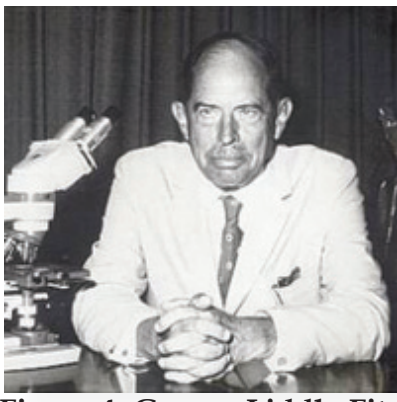

Figure 4. George Liddle Fite (1933-1993).

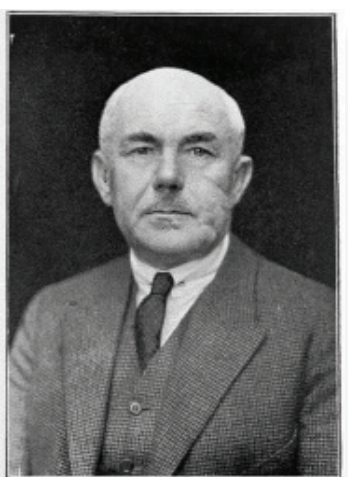

Figure 5. Gustav Giemsa (1867-1948).

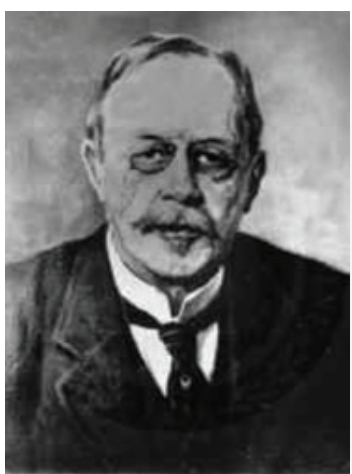

Figure 6. Hans Christian Gram (1853-1938).

\begin{tabular}{|c|c|}
\hline $\begin{array}{l}\text { Eponyms in the dermatology } \\
\text { literature linked to stains used in } \\
\text { skin biopsies }\end{array}$ & Remarks \\
\hline McCallum - Goodpasture stain & $\begin{array}{l}\text { It is a stain for bacteria using aniline fuchsin.. Named after William George Maccallum (1874- } \\
\text { 1944), (Fig. 8), who was a Canadian pathologist and Ernest William Goodpasture (1886-1960), } \\
\text { (Fig. 9), who was an American pathologist. }\end{array}$ \\
\hline Verhoeff-Van Gieson stain $[14,15]$ & $\begin{array}{l}\text { Also known as Verhoeff's Stain or Verhoeff's Elastic Stain (VEG) .In this stain, elastic fibers } \\
\text { will appear black.As an examples of its uses in dermatology,elastic fibers will be absent or } \\
\text { reduced in scar, middermal elastolysis, anetoderma, and cutis laxa.As another example, the elastic } \\
\text { fibers, will be distorted in pseudoxanthoma elasticum. The stain was developed by Verhoeff in } \\
\text { 1908.Frederick Herman Verhoeff (1874-1968), (Fig. 10), was an american ophthalmic surgeon } \\
\text { and pathologist .Ira Thompson Van Gieson (1866-1913), (Fig. 11), was an american neuropsy- } \\
\text { chiatrist and pathologist. }\end{array}$ \\
\hline Von Kossa Stain [16] & $\begin{array}{l}\text { A silver stain that stains calcium salts black originally developed by Von Kossa in } 1901 . \\
\text { Examples of its uses in dermatology include, pseudoxanthoma elasticum, calcinosis cutis, and } \\
\text { calciphylaxis. }\end{array}$ \\
\hline Warthin-Starry (WS) stain [17] & $\begin{array}{l}\text { Technically more difficult than the other stains, so sometimes referred as the ,'worthless Starry". } \\
\text { It is one of the Silver stains, which include, Dieterle stain and Steiner stain (a modified Dieterle } \\
\text { stain). It stains spirochetes black. } \\
\text { Examples of its uses include, lyme disease, and syphilis. Aso stain Legionella, Bartonella, } \\
\text { and Donovan bodies of granuloma inguinale. WS was first introduced in } 1920 \text { by American } \\
\text { pathologists, Aldred Scott Warthin (1866-1931), (Fig. 12), and Allen Chronister Starry (1890- } \\
\text { 1973). Currently immunohistochemistry is the best method to diagnose syphilis in skin biopsies. }\end{array}$ \\
\hline Ziehl-Neelsen stain $[18,19]$ & $\begin{array}{l}\text { Also known as the acid-fast stain, which is used to identify acid-fast bacteria. In this stain, } \\
\text { Mycobacteria will appear bright red. } \\
\text { Dr. Franz Ziehl (1857-1926), (Fig. 13), was a German bacteriologist. He was a professor in } \\
\text { Lübeck. } \\
\text { Franz Ziehl introduced the carbolfuchsin stain for the tubercle bacillus in } 1882 \text {. With a Friedrich } \\
\text { Carl Adolf Neelsen (1854-1898), (Fig. 14), who was a German pathologist, he developed the } \\
\text { Ziehl-Neelsen stain. }\end{array}$ \\
\hline
\end{tabular}

Table I. Selected Eponyms in the dermatology literature linked to stains used in skin biopsies (continued).

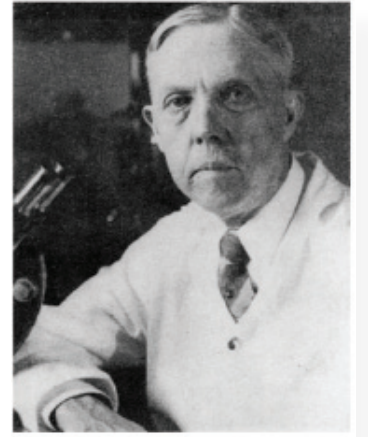

Figure 7. Claude L. Pierre Masson (1880-1959).

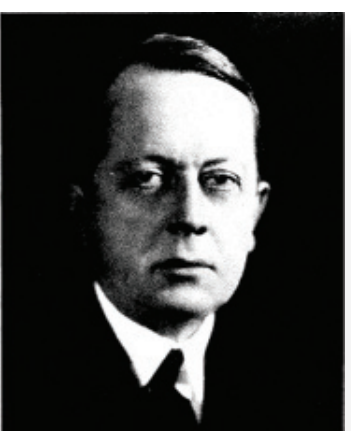

Figure 8. William George Maccallum (1874-1944).

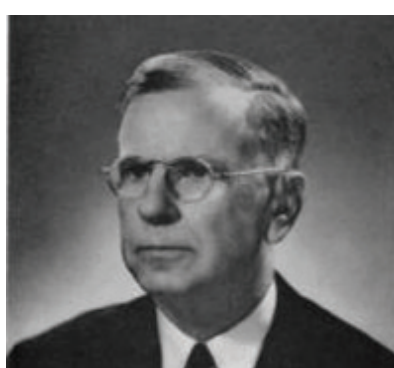

Figure 9. Ernest William Goodpasture (1886-1960). 


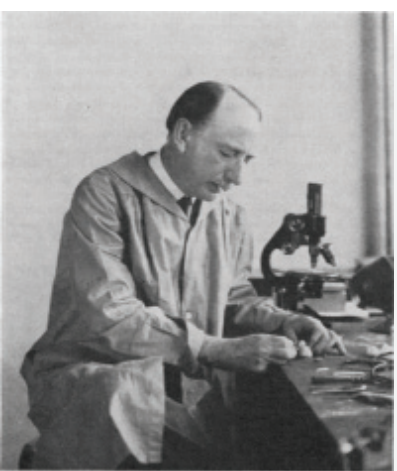

Figure 10. Frederick Herman Verhoeff (1874-1968).

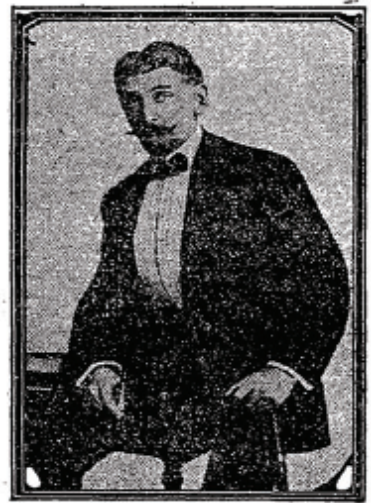

Figure 11. Ira Thompson Van Gieson (1866-1913).

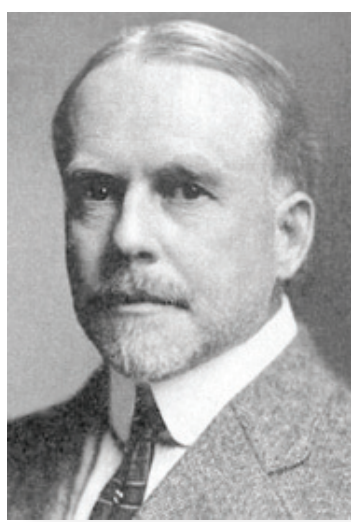

Figure 12. Aldred Scott Warthin (1866-1931).

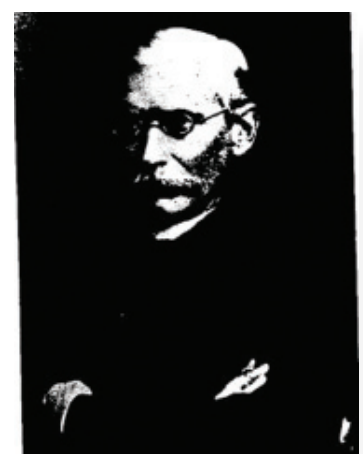

Figure 13. Franz Ziehl (1857-1926).

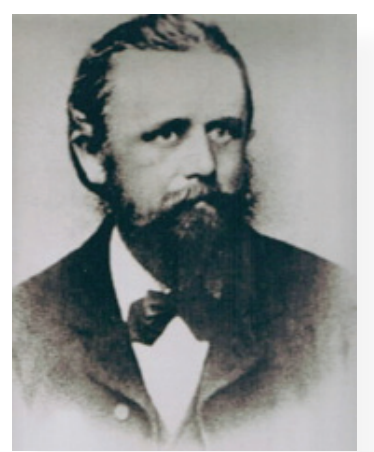

Figure 14. Friedrich Carl Adolf Neelsen (1854-1898).

\section{REFERENCES}

1. Staining.Wikipedia ${ }^{\circledR}$ [Internet]. Wikimedia Foundation. [Updated 5 May 2013; cited 5 May 2013]. Available from: http://en.wikipedia. org/wiki/Staining

2. Kimura M, McGinnis MR: Fontana-Masson--stained tissue from culture-proven mycoses. Arch Pathol Lab Med. 1998;122:1107-11.

3. Norton SA: Useful plants of dermatology. IV. Alizarin red and madder. J Am Acad Dermatol. 1998;39:484-5.

4. Al Aboud K, Al Aboud D: Eponyms in the dermatopathology literature linked to the neural tissues. Our Dermatol Online. 2013;4:395-8.

5. Kasten FH: Robert Feulgen and his histochemical reaction for DNA. Biotech Histochem. 2003;78:45-9.

6. Al Aboud K, Al Aboud A: A mini-review on eponyms in the dermatology literature linked to USA. Our Dermatol Online 2013; 3(Suppl.1):409-13.

7. Barcia JJ: The Giemsa stain: its history and applications. Int J Surg Pathol. 2007;15:292-6.

8. Puchtler H, Meloan SN, Waldrop FS: Aldehyde-fuchsin: historical and chemical considerations. Histochemistry. 1979;60:113-23.

9. Lillie RD: George Gomori; 1904-1957. J Histochem Cytochem. 1957;5:203.
10. Ruocco E, Baroni A, Donnarumma G, Ruocco V: Diagnostic procedures in dermatology. Clin Dermatol. 2011;29:548-56.

11. Al Aboud K, Al Aboud A: Eponyms in dermatology literature linked to Canada. Our Dermatol Online. 2013;4:113-6.

12. Malkin HM: History of pathology. William G. MacCallum (18741944). Ann Diagn Pathol. 1999;3:328-9.

13. Dawson JR Jr: Ernest William Goodpasture. (1886-1960). Am J Pathol. 1961;38:127a-a.3.

14. [No authors listed]: Fredrick Herman Verhoeff, 1874-1968. Br J Ophthalmol. 1969;53:71-2.

15. Aruin LI: [Ira RA Thompson van Gieson. (on the 50th anniversary of his death)]. Arkh Patol. 1963;25:51-2.

16. von Kossa J: Ueber die im Organismus kunstlich erzeugbaren Verkalkungen. Beit Path Anat. 1901;29:163.

17. Brennan PA: Aldred Scott Warthin (1866-1931). Br J Oral Maxillofac Surg. 2003;41:255.

18. Bishop PJ, Neumann G: The history of the Ziehl-Neelsen stain. Tubercle. 1970;51:196-206.

19. Al Aboud K, Manish P, Ramesh V: Eponymous laboratory stains in dermatology. J Pak Assoc Dermatol. 2008;18:167-70.

Copyright by Khalid Al Aboud, et al. This is an open access article distributed under the terms of the Creative Commons Attribution License, which permits unrestricted use, distribution, and reproduction in any medium, provided the original author and source are credited. 